\title{
ACCOUNTANCY HIGHER EDUCATION: EVOLUTION IN DIGITAL TECHNOLOGIES ADOPTION
}

\author{
Adriana Silva Carcavallo \\ University of São Paulo, Brazil
}

\begin{abstract}
The digital technologies are increasingly present in the daily life as we can notice through the dissemination of smartphones with countless apps that brought innovation in the manner people interact, access information and learn. The educational environment is not aloof from this digital evolution and there are several initiatives to apply technologies in the education on several subjects, being this paper focused on Accountancy undergraduate program. This paper is based on a qualitative research method comprising the review of the literature as well as the participant observation of two semesters of the course Accounting Information Systems at the University of São Paulo. It is possible to observe that the digital technologies increase the dynamics in the teaching-learning process, however it is necessary to be mindful that the technology is not the end, instead it is the mean. The digital technology use has a broader impact than a mere tool, because the current technologies have potential to interact with people and allow them to reorganize their thinking process. For scholars, several possibilities unfold to fulfill the learning objectives, going far beyond blackboard and books. For professors, there is the challenge of being trained, adapt and incorporate the technologies in the classroom.
\end{abstract}

\section{KEYWORDS}

Digital Technologies, Education, Accounting

\section{INTRODUCTION}

The human history encompasses the evolution in the way assets, liabilities, equities, production costs, profits and several other items are valued and booked since the times of Luca Pacioli. Nowadays, with the information technology present in the enterprise information systems known as ERPs, several automatic postings are included in its accounting processes that in essence refer to the gist of the double-entry bookkeeping.

The accountancy education is not dissociated from this evolution, once the traditional lectures that were mostly expository already can count on digital technologies to change the teaching-learning scenario. In a broader sense, it is noticed the importance of avoiding that the students stay aloof from the new technologies that surround the business environments that are beyond the academia.

This reflection paper analyzes how the theoretical reference approaches the digital technologies in the accountancy education. Will it perceive it as an additional tool? Will it be a replacement for the expository lecture? Will it have an approach towards programing logic or data modeling? Or, even further, will it be an ally in the human-computer interaction resulting in new ways of thinking, learning and teaching?

In order to accomplish its objectives, this research adopts a methodology that consists of literature review, a reflection based on the researched authors and an observant participation example of digital technology applied in the accountancy undergraduate course in the University of Sao Paulo.

\section{EVOLUTION IN DIGITAL TECHNOLOGIES ADOPTION}

First, a brief definition of technology in education according to Barros (2017): the education technology comprises all resources and tools used in the process of teaching and learning. In this definition, it is necessary to highlight that the core is the education and that the technologies are the means not the end, thus the human aspects of education and interactions between the individuals are maintained. 
This research presents an analogy of the digital technologies phases in the mathematics education according to Borba, Scucuglia and Gadanidis (2015) and the phases in the Accountancy education. The transition between each phase has distinguished scenarios, since the use of a new educational technology resource added originality to the thinking process with technology. The Table 1 summarizes several breakthroughs that can be seen between the transitions of phases such as evolution in computer processing, high speed internet improvements and scalability with more people accessing digital technologies.

Table 1. Evolution of digital technologies usage in Education

\begin{tabular}{|c|c|c|}
\hline Phase & Technologies & Events \\
\hline \multirow[t]{2}{*}{ Phase I - 80's } & Computers & Calculator HP $12 \mathrm{C}$ \\
\hline & Calculators & launched in 1981 \\
\hline Phase II - beginning 90's & Popularization of computers & $\begin{array}{l}\text { Spreadsheets } \\
\text { (Microsoft Excel®) }\end{array}$ \\
\hline Phase III - End of 90's & Computers, laptops and internet & $\begin{array}{l}\text { Teleduc, e-mail, chat, } \\
\text { forum, google }\end{array}$ \\
\hline \multirow[t]{5}{*}{ Phase IV - After year 2004} & Computers & Youtube \\
\hline & Laptops & Virtual Learning \\
\hline & Tablets & Environment \\
\hline & Smartphones & Wikipedia \\
\hline & Faster Internet Speed & Apps \\
\hline
\end{tabular}

In each phase there were challenges and opportunities disrupting traditional approaches. According to Barros (2015), it is possible to distinguish technophiles and technophobes, being the first with a positive perception of technology adoption while the technophobe sees negative aspects and resistance that might be linked to a trend to stay in the comfort zone. The ideal is that education professionals have critical thinking to evaluate both positive and negative aspects of technology in the teaching-learning process.

The use of calculators and spreadsheet applications, for instance, could be seen by technophiles as a way to optimize the resolution of more complex calculations resulting in more time to think about the logic and problem resolution instead of repetition of mechanical calculations. On the other hand, technophobes can argue that calculations should be done manually in order to avoid the students' dependency on technology and a scenario in which they are not able to perform the calculations without a calculator or a spreadsheet application. Concerning internet in the education, it can be used as a tool to expand knowledge as well as a distraction, being necessary a good dosage of its use to avoid that students are overwhelmed with a lot of information contrasting with little assimilation.

An approach to be considered is that education technology is not a mere tool to replace or an accessory to help the execution of tasks, it can have a broader usage in enabling the reorganization of the thinking process, since there is the constant interaction between individuals and technologies in a sequence of inputs and outputs (Tikhomirov, 1981 as cited in Borba and Penteado 2016).

In the book The One World Schoolhouse, Samal Khan, the creator of the Khan Academy, among other considerations, observes how digital technologies can enable the flipped classroom approach in which the videos of explanatory classes can be seen as homework while in the classroom the activities are focused on discussion, problems' resolutions and interaction between students and teachers. By watching the explanations in the videos, students can pause and repeat the video as many times as necessary and make their notes in a pace that does not affect the pace of other students learning and besides allowing the students to expand horizons if their curiosity leads them to make more research on the theme (KHAN, 2013).

\subsection{Example of Digital Technology in Accountancy Higher Education}

Several digital technology options are available nowadays to be used in the teaching-learning process. Some of these were specifically designed for educational purposes such as Khan Academy, others can be incorporated in the classes for educational purposes. In this paper, we will see an example of digital technology usage in an Accounting Information Systems course in an occasion that the author of this paper participated as tutor in the classes. The tutor role of the author was performed as part of the Teaching Improvement Program in the University of Sao Paulo known as PAE (Programa de Aperfeiçoamento de Ensino). 
This Accounting Information Systems course had its program and some materials such as power-point presentations available in the course portal. In addition to that, the class had activities on an actual ERP system in order to familiarize students with the way the companies maintain information and transactions in such system.

The use of the ERP in class was possible thanks to a partnership between the course professor and the professionals from an ERP company. The students received an individual remote desktop access to a laboratory ERP system. With this remote desktop access, they were able to connect to the system from home anytime as well as during the class from their own laptops or from the computer lab in the university. A list of activities was provided to the students and they had assignments to maintain master data, create chart of accounts, make some accounting postings and display their results on the system.

All the students' tasks were captured in the system log allowing the professor and the tutor to monitor which students completed the activities and which ones needed more guidance. The students had additional support through an e-mail communication to clarify questions or solve issues. In this learning process, the students were constantly facing the cycle of inserting inputs in the system, executing, receiving warnings when some input was wrong or receiving the confirmation that the outputs were the expected ones. This was an ongoing process rather than a final exam date when everything is evaluated in a single event.

\section{CONCLUSION}

The role of digital technologies is becoming more comprehensive than a tool because of its interactivity characteristics that are promoting a new reorganization of the thinking process to teach and learn. Specifically, in the example presented of the Accounting Information Systems course, it was noticed the transition between the theoretical concepts about chart of accounts, accounting postings and ledger to a translation in terms of the modelling of information systems, which for some students represented their first contact to the practice using a system designed to be used by companies. The usage of the logs from the system provided a new evaluation method because the students knew the system was tracking what they were doing without the need that they present or deliver a written task.

Future researches on this theme can count on case studies about technologies applied in the business courses, the flipped classroom approach and also there are opportunities of multi-disciplinary studies with neuroscience related to the reorganization of thought in the learning process with digital technologies. It will be interesting also to perform interviews with professors about the challenges they face to keep up with the innovations in the digital technologies in education. Besides that, learn from the professors which adaptations they have done in their teaching methodologies that differ from the way they were taught at the time they were students.

\section{REFERENCES}

Barros, G. C., 2017. Tecnologias e Educação Matemática: projetos para a prática profissional. Intersaberes, Curitiba, Brazil.

Borba, M. C.; Penteado, M. G., 2016. Informática e Educação Matemática. Coleção Tendências em Educação Matemática, Autêntica, Belo Horizonte, Brazil.

Borba, M. C.; Scucuglia, R. R. S.; Gadanidis, G., 2015. Fases das Tecnologias Digitais em Educação Matemática: sala de aula e internet em movimento. Autêntica, Belo Horizonte, Brazil.

Khan, S., 2013. The One World Schoolhouse: education reimagined. Twelve, New York, USA.

Rolkouski, E., 2012. Tecnologias no ensino de matemática. Intersaberes, Curitiba, Brazil.

Souza, M.C.D., 2016. Análise das contribuições dos Objetos Educacionais Digitais para a construção do conhecimento em Matemática na Educação Básica. Master's Degree Thesis, Instituto de Matemática e Estatística, Universidade de São Paulo, São Paulo, Brazil. 